\title{
Uniform Patterns Regarding Same-Sex Relationships
}

IAN CURRY-SUMNER*

\section{Introduction}

In April 2001, The Netherlands became the first country in the world to allow same-sex couples to legally marry. Although such a move remains restricted to a small (yet increasing) number of jurisdictions around the world, the tide in the fortunes of same-sex couples is changing. ${ }^{2}$ Until recently, gays and lesbians were for all intents and purposes legally invisible. Frightened of discovery, gays and lesbians lived at risk of persecution and prosecution. But the dawn of a new millennium has ushered in a new era. Gone are the days of criminal prosecutions for homosexuality in Europe. ${ }^{3}$ Gone too are the days when European homosexuals were sentenced to psychological treatment for their "disease". Yet, unfortunately, distant history it is not. It was not until 1993 that the World Health Organisation removed homosexuality from its list of diseases, and not until 2003 that Armenia decriminalised homosexuality.

This new era of tolerance and acceptance has also heralded a willingness to recognise the stability and value of same-sex relationships. It is this mounting attention paid to the recognition of same-sex relationships that will form the focal

\footnotetext{
* Junior Lecturer/Researcher of private international law, comparative law and family law, Molengraaff Institute for Private Law, Utrecht University, The Netherlands. The author is currently in the final stages of his doctoral research on the private international law aspects of non-marital registered relationships in Belgium, France, The Netherlands, Switzerland and the United Kingdom. This research is due to be published in November 2005 by Intersentia, Antwerp in the European Family Law Series under the title "All's well that ends registered?". Publications prior to April 2005 were published under the name Ian Sumner.

1 Staatsblad 2001, No.9.

2 Belgium: Act of $13^{\text {th }}$ February 2003, Staatsblad, 28 $8^{\text {th }}$ February 2003; Ontario, Canada: Halpern et al v. Canada (2003) 65 OR (3d) 161; Quebec, Canada: Hendricks and Leboeufv. Quebec [2002] RJQ No. 2506; British Columbia, Canada: Babeau v. British Columbia 2003 BCCA 251; Yukon Territory, Canada: Dunbar \& Edge v. Government of Yukon (AG) [2004] YJ No. 61 (QL); Manitoba, Canada: Vogel v. Canada [2004] MJ No. 418 (QL); Nova Scotia, Canada: Boutilier v. Nova Scotia [2004] NSJ No. 357 (QL); Saskatchewan, Canada: NW and JR et al v. Canada [2004] SJ No. 669 (QL); Newfoundland, Canada: Pottle and French v. Canada (21 ${ }^{\text {st }}$ December 2004). Same-sex marriage has recently also been introduced in Spain and at federal level in Canada.

Since 2003, homosexuality has been decriminalised in all forty-five Member States of the Council of Europe.
}

International Law FORUM du droit international 7: 186-194, 2005.

(02005 Koninklijke Brill N.V., Leiden, The Netherlands. 
point of this article. Although gays and lesbians continue to fight for individual freedoms around the globe, those issues will not be addressed here.

At this juncture it is also important to note two approaches to the problems associated with the legal recognition of same-sex relationships: the cohabitation approach and the registration approach. ${ }^{4}$ In the cohabitation approach, which can also be described as an "opt-out system," couples are automatically granted limited rights, duties and protection, on the basis of the fulfilment of pre-determined conditions. These conditions often relate to minimum periods of cohabitation, as well as minimum age, residency and exclusivity requirements. In the registration approach, often described as an "opt-in system," couples are only entitled to certain rights and duties once they register their relationship in accordance with domestic substantive law. Although the sole focus of this article will be on the registration approach, it is important to note the extensive use of the cohabitation approach both inside and outside of Europe, especially in Australia and New Zealand. ${ }^{5}$ It is also important to stress that these approaches need not operate exclusively. In France, for example, both approaches were introduced in the same piece of legislation, ${ }^{6}$ whereas in Sweden the cohabitation approach predated the registration approach by little under a decade. ${ }^{\top}$

\section{Uniform Patterns}

Turning to the registration approach, the task laid before comparative lawyers is whether uniform trends can be discerned. In 1989, Denmark became the first country in the world to introduce a registration scheme for same-sex couples. ${ }^{8} \mathrm{At}$ that time, no one could have predicted the exponential increase in the number of jurisdictions to follow in Denmark's footsteps. At the time of writing, this

\footnotetext{
4 See R. Wintemute, "Conclusions", in R. Wintemute and M. Andemæs (eds.), Legal recognition of same-sex partnerships. A study of national, European and international law, Oxford/Portland, Oregon: Hart, 2001, p. 759-773.

5 See, e.g., the Property (Relationships) Act 1984 (New South Wales), Property Law Act as amended (Queensland); Ptoperty Law Act as amended (Victoria), Domestic Relationships Act 1994 (Australian Capital Territory), Relationships Act 2003 (Tasmania), De Facto Relationships Act 1996 (South Australia, although restricted to opposite-sex couples), De Facto Relationships Act 2004 (Northern Territory) and Property (Relationships) Amendment Act 2001 (New Zealand).

6 Articles 515-1 to 515-7, French Civil Code creare a registration schemes entitled the pacte civil de solidarité whilst Article 515-8, French Civil Code formally recognises a non-registered form of concubinage.

7 Cohabitees (Joint Homes) Act 1987 and Homosexual Cohabitees Act 1987.

8 Act $N^{\circ} .372$ of $7^{\text {th }}$ June 1989.
} 
author is aware of forty jurisdictions worldwide to have introduced a similar or comparable form of registry for same-sex couples. The diversity of these regulations has sparked calls for a private international law instrument; ${ }^{9}$ others have argued that the multiplicity and variety of such registration schemes is illustrative of the present lack of uniformity of approach in the field of family law. ${ }^{10}$ But are these registration schemes in fact so diverse? Are there no signs of common tendencies and uniform approaches?

In attempting to answer these questions, it is important to distinguish between two separate yet interrelated facets of these registration schemes. Firstly, one must examine the conditions imposed on those wishing to register their relationship. Who may and may not register their relationship? Prior to registration, both parties must satisfy a number of formalities. For example, both parties will normally be required to have reached a certain age, often equivalent to the age of majority or the age requirement imposed on those wishing to marry. Although numerous other conditions must also be satisfied before two persons will be entitled to register their relationship, only two of these requirements will be dealt with here, namely those relating to residency and gender.

Secondly, it is also important to note the different approaches regarding the extent of the rights and duties attributed to the parties. In Belgium, for example, parties to a statutory cohabitation are only entitled to limited rights and duties in the field of property law. ${ }^{11}$ At the other end of the spectrum, other jurisdictions have chosen to create a replica marital status. ${ }^{12}$ Despite this variety of approaches, some uniform patterns can be identified. In coupling these trends with those identified in the field of entry requirements, one is able to distinguish a number of different models of same-sex relationship regulation.

\section{Registration of a Same-Sex Relationship}

When Denmark created a registration scheme, restrictions were imposed with regard to the parties' residence as well as their nationality. ${ }^{13}$ In this way, the problems of

$9 \quad$ K. Boele-Woelki, "De wenselijkheid van ee IPR-verdrag inzake samenleving buiten huwelijk", Tijdschrift voor familie-en jeugdrecht, 1999, p. 11-13.

10 P. Senaeve, Closing speech at the 2003 lus Commune Conference in Maastricht, to be pubilished in the lustrum issue of Jura Falconis later this year.

"Wet van 23 november 1998 tot invoering van de wettelijke samenwoning/Loi instaurant la cohabitation légale de 23 novembre 1998 .

12 In Sweden, for example, the only difference between marriage and registered partnership lies in the field of artificial insemination.

13 One of the parties needed to be a Danish citizen and permanently resident in Denmark. I. Lund-Andersen, "The Danish Registered Partnership Act", in K. Boele-Woelki and A. 
an international nature and "registration tourism" were significantly reduced. ${ }^{14}$ These considerations appear to have become somewhat of a recurring theme in other jurisdictions too. Nonetheless, it would appear that the initial wave of strict residency requirements has crested. In Denmark, for example, these rules have now been altered so as to allow a partnership to be registered as long as both parties have been permanently resident in Denmark. ${ }^{15}$ Furthermore, Denmark has placed Norwegian, Swedish and Icelandic citizenship on an equal footing with Danish citizenship. ${ }^{16}$ In The Netherlands, the initial disparity between the more stringent residency requirements imposed on those wishing to register a partnership, as compared to those wishing to celebrate a marriage, has also been removed. ${ }^{17}$

One is able, however, to proffer a relatively candid explanation for this initial stringency and subsequent relaxation. Not wishing to create limping relationships, ${ }^{18}$ while at the same time desiring to improve the domestic situation for same-sex couples, national legislatures were left with few options other than to introduce strict residency requirements. Although the fears of "registration tourism" have played enormously on the minds of legislatures around the globe, such fears have not yet been realised. As more jurisdictions begin to enact legislation protecting same-sex couples, the need to introduce residency requirements that differ from those imposed on aspirant spouses lessens. The recent enactment of the Civil Partnership Act of 2004 in the United Kingdom indicates this decreasing need, with couples being subject to identical residency requirements as those of aspirant spouses despite the relative leniency of those conditions. ${ }^{19}$

Turning to the gender requirements imposed on aspirant couples, two distinct approaches can be discerned. In some countries, registration is restricted to couples of the same-sex, whereas in others, registration is also open to opposite-sex couples. It is therefore constructive at this point to analyse the registration schemes in the

Fuchs (eds.), EFL series: Volume 1. Legal recognition of same-sex couples in Europe, Antwerp: Intersentia, 2003, p. 19.

14 "Registration tourism" refers to the believe that couples with no connection to a particular country will travel to have their relationship registered and then move back to their home State.

15 Sec. 2(2)(ii), as amended by Act No. 360 of $2^{\text {nd }}$ June 1999.

16 Sec. 2(3), as amended by Act $\mathrm{N}^{\circ} .360$ of $2^{\text {nd }}$ June 1999.

17 Staatsbald 2001, No. 11.

18 This private international law term refers to relationships which although recognised in one relationship are not subsequently recognised in other jurisdictions. These are known as relations boite $x x$ in French.

19 Only seven days residency is required in England \& Wales (Sec. 8(1)(b), Civil Partnerships Act 2004), whilst no residency is required in Scotland or Northern Ireland. 
broader framework of instirutionalised/formalised intimate relationships. Under this analysis, three distinct models can be distinguished.

1. Monistic MODel. Under this approach, no separate registration scheme for samesex couples is created. Instead the prohibition on same-sex marriage is removed, in turn creating a single, formalised institution open both to same-sex and opposite-sex couples, namely marriage. This approach has only been followed in a relatively small number of jurisdictions, namely in Ontario, British Columbia, Yukon Territory, Saskatchewan and Newfoundland in Canada, and Massachusetts in the USA. ${ }^{20}$ Political resistance and sensitivity to make such a monumental change to existing legislation is part of the reason for the relatively low adoption of this model. As a result, this model is, at present, restricted to common law jurisdictions where judges have taken the initiative to strike down gender-based marital restrictions, often on the basis of their unconstitutionality. Spain has recently become the first civil law country to have enacted same-sex marriage legislation prior to the enactment of a national non-marital registration scheme. ${ }^{21}$

2. DuALISTIC MODel. Under this approach, a registry which is restricted to same-sex couples is created. Opposite-sex couples wishing to formalise their relationship are able to do so via traditional marriage. In this model, two institutions operate side-by-side; one for opposite-sex couples, i.e., marriage, and one for same-sex couples, i.e. a form of registered partnership. This approach has been followed in Argentina (Río Negro), Denmark, Finland, Germany, Greenland, Iceland, Norway, Slovenia, Sweden, Switzerland, the UK (England \& Wales, Northern Ireland and Scotland) and the states of Connecticut and Vermont in the USA.

3. PluRAlistic model. Under this final approach, a registry scheme which is open to both same-sex and opposite-sex couples is created. Opposite-sex couples are therefore provided with a choice of institutional forms: marriage or registration. Same-sex couples, on the other hand, are provided with only one option: registration. The pluralistic model has been followed in Andorra, Argentina (Buenos Aires), Australia (Tasmania), France, Luxembourg, New Zealand, Spain (Andalucia, Aragon, Asturias, Balearic Islands, Basque Country, Canary Islands, Catalonia, Extremadura, Madrid, Navarre and Valencia) and the states of California, ${ }^{22}$

20 Recent federal-wide legislation has also legalised same-sex marriage across Canada.

21 Ley 13/2005 de 1 julio 2005 por la que se modifica el Código Civil en materia de derecho a contraer matrimonio, BOE No. 153. This statement must be cautioned by the fact that eleven autonomous regions of Spain have already legislated on this topic.

22 Restricted to opposite-sex couples over the age of 62: $\$ 297$ (b)(5)(B), Part 1, Division 2.5. California Family Code. 
Hawai $\mathrm{i},{ }^{23}$ Maine and New Jersey ${ }^{24}$ in the USA. ${ }^{25}$ In choosing this route, the arguments for opening marriage to same-sex couples are strengthened due to the continued difference in treatment. In The Netherlands, Belgium, Manitoba, Nova Scotia and Quebec, these calls have been duly met and civil marriage has indeed been opened up to same-sex couples, creating a truly pluralistic system for all.

\section{Attributed Rights and Duties}

A different yet interconnected facet of these new relationship schemes relates to the package of rights and duties attributed to those who register their relationship. Although it is almost impossible to make discrete distinctions between different approaches, a rough continuum can be perceived among the currently enacted schemes. The rights and duries attributed to those who have registered their relationship can be divided into four categories: property rights, fiscal rights, family law partnership rights, and family law rights relating to children.

Property rights and duties are generally of a low political sensitivity. It is assumed that parties involved in an intimate relationship wish to commit to each other, and by imposing duties, such as a duty to cohabit or contribute to the costs of the household, the State is merely indicating its moral stance at little financial burden to itself. Although opinions as to the best or most proper matrimonial property regime differ markedly and have resulted in protracted political debates in many countries, the question of whether to enact rules that determine the property law effects of registering a non-marital relationship is by and large uncontroversial. Moreover, in many legal systems, the parties themselves are in any case able to draw up a contract regulating such issues; the State simply provides for a default system to operate in the absence of such an expression of the parties' will. In addition, it appears that in any debate concerning the protection that should be offered to cohabitants, discussion centres on this field of law. ${ }^{26}$ It is therefore not surprising that

23 Restricted to opposite-sex couples with the prohibited degrees of marriage: $\$ 572 \mathrm{C}-4(3)$, Title 31, Division 3, Hawai i Revised Statutes Annotated.

24 Restricted to opposite-sex couples over the age of 62: C.26:8A-4b(5), Chapter 246, PL 2003.

25 These jurisdictions have only succeeded in achieving the first stage, i.e. the creation of a registration scheme open to all, but maintaining the gender restrictions imposed on marriage.

${ }^{26}$ See, e.g., W. Schrama, De niet-huwelijkse samenleving in het Nederlandse en Duitse recht, Amsterdam: Ars Notariatus, Kluwer, 2004; A. Barlow, Cohabitants and the law, London: Butterworths, 2001, $3^{\text {rd }}$ Edition; P. Senaeve (ed.), Concubinat. De buitenhuwelijkse tweerelatie, Leuven: Acco, 1992. 
this field of law is one of the first to be legislated upon for non-marital registered relationships.

Although fiscal rights and duties are generally of a less sensitive political nature than family law rights, the extension of fiscal benefits in the form of tax breaks, social security benefits and access to pension schemes obviously comes at great financial cost to the Government. The political will to remove fiscal discrimination is therefore often pitted against the available funds in the financial coffers.

As one moves towards the area of family law partnership rights, one senses a shift in emphasis. If the extension of rights into this field is accepted, it becomes more difficult to draw distinctions: upon extending one right or duty, one must justify the almost unjustifiable, in denying the extension of orher rights in this category. Rights and duties in the field of family law also have a long-standing association with the law on marriage in many countries. On the European continent, the celebration of a marriage has an important impact on those personal law rights associared with a person's civil status, name and nationality. This is to some extent also true of common law countries, where according to old authorities the celebration of a marriage for many purposes, fused the legal personalities of husband and wife into one. As a result, the extension of such rights to those outside of the marital bond is a much more sensitive matter than the rights in the first two categories.

The category of family law rights in relation to children, untouched in a vast majority of legal systems, is possibly the most sensitive of all. This sensitivity stems from a multiplicity of dynamic factors: biology, tradition, third-party rights, and moral values. The law on parentage was originally based on the presumption of biology. The idea of extending such presumptions to same-sex couples involves an enormous excursion from reality. Even if the husband of the legal mother is not the father of the child, there is a biological possibility that he could be, whereas such a biological possibility is completely absent in same-sex couples. ${ }^{27}$

The more rights and duties a Government attaches to a registration scheme, the stronger it is deemed to be. In general, those registration schemes with rights and duties restricted to the first two categories are deemed to have opted for a "weak registration scheme," whereas those moving into the latter two categories have opted for a "strong registration scheme." ${ }^{28}$ Although this division into rough categories of rights is merely illustrative and does not profess to be used for any higher purpose,

27 Kortmann Commissie, Commissie inzake openstelling van bet burgerlijk huwelijk voor personen van hetzelfde geslacht, The Hague: Ministry of Justice, 1997 , p. $5, \$ 2.1$.

28 R. Wintemute, "Conclusions", in R. Wintemute and M. Andemæs (eds.), Legal recognition of same-sex partnerships. A study of national, European and international law, Oxford/Portland, Oregon: Hart, 2001, p. 759-773 at 766. 
it is perhaps effective in helping to identify the crucial difference between those countries adhering to a system of "strong registration" and those adopting a system of "weak registration." Of course, any global classification on this superficial basis will be subject to exceptions and it is admitted that these divisions are merely an aid in an attempt to discern general uniform trends in this field.

\section{Choices and Reasoning}

Although the determination of uniform patterns is important, it is equally important to understand the underlying rationale for their existence. In choosing between the monistic, dualistic and pluralistic models, a number of factors play a role. In some jurisdictions marriage is afforded constitutional protection. In Germany, for example, Article $6(1)$ of the German Constitution provides that "marriage and the family shall enjoy the special protection of the State." As a result, it would have been political suicide to attempt to introduce a registration scheme offering opposite-sex couples an alternative to marriage. Furthermore, the role of the church in the celebration of marriages often plays a determining factor in the approach adopted by a particular jurisdiction. In the United Kingdom, as well as in Denmark, Norway and Iceland, recognised religious bodies or State churches are legally entitled to celebrate marriages. Any debate on opening registration to opposite-sex couples would therefore have stumbled on the associated religious objections. If neither of these factors are present, the objections to opening registration schemes to opposite-sex couples are much weaker. If either or both of these factors are present, it would appear that a legislature is more inclined to meander down the pluralistic path. Moreover, the monistic path appears, at present, only to have been approached by judges who have declared the prohibition on same-sex marriage to be unconstitutional.

Opening registration to opposite-sex couples and opting for the pluralistic model does not necessarily go hand-in-hand with a weak registration scheme. In The Netherlands, for example, although both same-sex and opposite-sex couples are entitled to register their partnership, the package of rights and duties associated with such a registration is almost identical to that offered to spouses. Similarly, in restricting registration to couples of the same-sex, jurisdictions do not necessarily endorse a strong registration scheme. A new trend of registration proposals is beginning to emerge from Eastern Europe, ${ }^{29}$ where the dualistic approach is coupled with a weak registration scheme. Politicians often see the need to confront issues relating to same-sex couples as a direct result of ascension to the European Union and an

29 Evidenced recently in the enactment of registered partnership in Slovenia: Zakon o registraciji istospolne partnerske skupnosti. 
imposition from beyond national frontiers. The reluctance with which these issues are addressed is reflected in the relatively restrictive nature of these proposals.

\section{The Future}

This article has shown that despite the diversity entrenched in the forty jurisdictions to have tackled these issues, uniform trends are perceptible. In a similar fashion to the division of the world into legal families, the formalised registration schemes for same-sex couples can be divided into five different models:

1. Monistic model, e.g. Massachusetts

2. Dualistic model with weak registration, e.g. Slovenia

3. Dualistic model with strong registration, e.g. UK, Switzerland

4. Pluralistic model with weak registration, e.g. France, Belgium

5. Pluralistic model with strong registration, e.g. The Netherlands, Quebec

Despite the variety of solutions, uniform trends of regulation can be discerned. The task for the future is to acknowledge the diversity with which we are confronted, yet at the same time appreciate the similarities. Given an ever increasingly mobile population, confrontation with registration schemes from abroad is only set to increase. The time is now ripe for a worldwide private international law instrument regulating the recognition of such relationships. Nothing in the five different models distinguished above negates the possibility of creating a single private international law instrument dealing with these new forms of non-marital registered relationships. It is now time to embrace diversity and recognise stable, intimate same-sex relationships. In contributing to the international discourse, it is hoped that this article will ensure that people at least pause before assuming that the diversity in national response is necessarily tantamount to non-comparibility of result. It can only be hoped that the vanguard jurisdictions will inevitably lead the way for the rest of the world in addressing the issues facing same-sex couples. 